\title{
The Investigation of the Relationship between the Level of Metacognitive Awareness, Self-directed Learning Readiness and Academic Achievement of Preschool Teacher Candidates*
}

\author{
Asude Balaban Dağal ${ }^{1, *}$, Dilan Bayındır² \\ ${ }^{1}$ Ataturk Education Faculty, Marmara University, Turkey \\ ${ }^{2}$ Necatibey Education Faculty, Balikesir University, Turkey
}

Copyright $\mathrm{C} 2016$ by authors, all rights reserved. Authors agree that this article remains permanently open access under the terms of the Creative Commons Attribution License 4.0 International License

\begin{abstract}
The aim of the study is to examine the relationship between the level of metacognitive awareness, self-directed learning readiness and academic achievement of preschool teacher candidates. The study group of the research, which was designed in survey method, included 151 teacher candidates from Atatürk Education Faculty, Preschool Teaching Department at Marmara University, Istanbul, Turkey. All of the candidates volunteered to participate to the study. The Demographic Form, The Metacognitive Awareness Inventory (MAI) and The Self-Directed Learning Readiness Scale (SDLRS) were used as the data collection tools. The academic achievement was determined by looking the grade point average of teacher candidates. The results of the research indicated that there was not a significant relationship between the level of metacognitive awareness and self-directed learning readiness with academic achievement of teacher candidates. A moderate relationship between the total scores of the metacognitive awareness and self-directed learning readiness was found.
\end{abstract}

Keywords Preschool Teacher Candidates, Metacognitive Awareness, Self-directed Learning, Academic Achievement

\section{Introduction}

Studies conducted on the learning and success of the students in last 30 years mention in detail, the effects of the cognitive strategies, metacognition, motivation, participation in tasks, and social support in the learning environment on these facts [1]. Considering the effects of the teachers on the students, the importance of investigating the relation of these variables of teachers is conspicuous.
The literature on (1) metacognition and metacognitive awareness, (2) self-directed learning, (3) academic success and (4) the relationship between metacognition and metacognitive awareness, self-directed learning and academic achievement are discussed as below.

\subsection{Metacognition and Metacognitive Awareness}

It is an accepted view that the concept of metacognition was brought into the developmental psychology by John Flavell in the mid-1970s [2]. This concept can be defined as monitoring and controlling the cognition, in other words as the individual's thinking of his/her own cognitive processes $[3,4]$. This concept is categorized in two basic groups of "knowledge about cognition" and "metacognitive skills". Knowledge about cognition means that individuals have knowledge about their own cognitive activities and cognitive strategies whereas cognitive skills define processes that organize and control cognition like planning, monitoring and evaluating [5]. The concept of metacognition emerges as a very popular area of studies especially in recent times. One of the important reason to this is that there is a positive relationship with metacognitive elements and academic success [6-9]. The relationship between metacognitive awareness and intelligence has been the topic for many researches. Some of these researches showed that there is a significant relationship between metacognition and intelligence $[10,11]$ whereas results of some researches propounded that these two variables are independent $[12,13]$.

The metacognitive knowledge and activities being teachable are among the results of the studies conducted [14-16]. Veenman, Von Hout-Walters and Afflerback [17] mention that these skills are learned from parents, peers and teachers. Metallidou [18], in her study conducted on teachers, found out that metacognitive knowledge increased the frequency of using problem solving strategies on classroom 
management and provided producing proper strategies. When considering the positive results of teachers having high levels of metacognitive awareness on classroom environment and students, it can be said that teachers should have these skills themselves.

\subsection{Self-Directed Learning}

Concepts like self-directed learning, self-planned learning, self-education, self-regulative learning, independent learning and open learning define the same phenomenon. Self-directed learning is defined by Knowles [19] as the process of being able to initiate for learning, define one's own learning needs either taking others help or not, establish learning goals, decide sources (individual, book etc.) for learning, choose and apply appropriate learning strategies for the knowledge and evaluate learning results. Drawing on Bandura's work, Zimmerman (1986) defined self-regulated learning as "the process whereby students activate and sustain cognitions and behaviors systematically oriented toward the attainment of their learning goals" [cited in 20]. According to Hiemstra [21], even it takes place in formal education environment; most of the learning activity is in the hands of the learning individual. This point of view stresses especially the control of the individual on his/her learning. For self-directed learning, individual has to decide the learning goals and strategies, make decisions on how to use the resources and how to evaluate the success, direct and sustain his/her motivation and make appropriate evaluations on learning process (Schunk, 2005 cited in 22]. In other words, self-directed learning helps students to acquire and establish strategies about guiding and regulating their own learning with an independent attitude [23]. As this point of view mentions, in every phase of the self-directed learning process the learner controls the learning process [24,21,25]. Patterson, Crooks and Lunyk-Child [26] pointed out that the individual should have six characteristics in order to achieve self-directed learning process. These are; awareness of the learning need, readiness for learning, acquiring the knowledge, managing the knowledge, thinking and critical evaluating. Achievement of the self-directed learning is associated with the motivation of the learner. If the individual believes in the importance of the learning and the usefulness of it, s/he will direct his/her attention more intensely to the learning process and will use more effective strategies for learning and recalling [Pintrich, 2005; Weinstein, Husman and Dierking, 2005 cited in 22]. According to Şahin and Erden [27], teachers should have these self-directed learning skills themselves in order to support their students'.

\subsection{Academic Achievement}

Researches show that the most important predictors of academic achievement are intelligence and level of motivation [28-33]. Among the other predictors for academic achievement; personality [34-37], attitudes towards learning [38] and learning styles [35] are also considered as effective. In recent years other concepts have emerged as predictors for academic achievement. The relationship between academic achievement and metacognition, which has emerged as one these variables, is being studied among different groups [1]. In many researchers conducted with university students, the grade point averages (GPA) of the students were taken as a basis for predicting the level of academic achievement [39]. Similarly this research takes GPAs of students as basis to evaluate academic achievement.

\subsection{The Relationship between Metacognition, Self-Directed Learning and Academic Achievement}

Metacognition is closely related to learning processes and academic achievement because it includes awareness of individual's own thinking processes and ability to control his/her own cognitive system [40,41]. Zimmerman [42] defines self regulation that is a broader concept covers also metacognition as "self directive process through which learners transform their mental abilities into task-related academic skilss" (p.1). Individuals with high metacognitive awareness are aware of what they know and do not know. Because these individuals are successful at planning, information management, contracting strategies, monitoring, debugging and evaluating, it can be said that this has a positive effect on their academic achievement $[43,44]$. By teaching metacognitive knowledge and skills, individuals can increase their influence on their learning processes [Ülgen, 2004 cited 45]. With the first component, knowledge about cognition, as described above provides more comprehension by observing and evaluating conceptual and operational activity, whereas metacognitive skills provide regulating individual's problem solving and learning activities [16].

This study aims to identify the relationship between (1) level of metacognitive awareness and readiness for self-directed learning with academic achievement and (2) level of metacognitive awareness and readiness of self-directed learning of preschool teachers. In this way, it was aimed to identify the level of metacognitive awareness and readiness for self-directed learning and contribute to literature by defining the relationship between these variables among preschool teachers.

\section{Methodology}

\subsection{Study Group}

The study group consisted of 151 teacher candidates studying at the Preschool Education Department at Atatürk Faculty of Education, Marmara University in the academic year of 2014-2015. All of the participants were junior students. 145 of the participants $(96 \%)$ were women and 6 of them $(4 \%)$ were men in the study group. 8 of the participants 
(5.3\%) identified their socio-economic status as low, 132 of them $(87.3 \%)$ as average and 11 of them $(7.3 \%)$ as high. Considering the average grade, 4 of the participants $(2.6 \%)$ have low, 85 of them (56.3\%) have medium/average and 61 of them $(40.4 \%)$ have high grade point average.

\subsection{Data Collection Tools}

2.2.1. Demographic Form: With the form developed by researchers, it is intended to obtain the demographic information (age, gender, income rate) of the teacher candidates in the study group of the research. Data on the academic achievement of the students were obtained by including the current GPAs of students into the demographic form.

\subsubsection{Metacognitive Awareness Inventory: The} metacognitive awareness inventory is a self-assessment tool to identify level of metacognition in adults and developed by Schraw and Sperling-Dennison [43]. It is a 52 item and 5 likert type inventory. Scores are ranging between 52 and 260. There are two basic dimensions in this scale. First dimension is "knowing about cognition", while the second dimension is "regulation of cognition". Under the dimension of "knowledge of cognition" there are 3 subscales. These are declarative knowledge, procedural knowledge and conditional knowledge. Second dimension has four subscales which are planning, information management, comprehension monitoring and debugging strategies. Inventory was adopted into Turkish by Akın, Abacı and Çetin [46] with a study done on university students. According to this, during reliability test of the scale, reliability coefficient acquired by test-retest was found 0.95 ; the reliability coefficient obtained by split-half method was 0.91; Cronbach's alpha coefficients were 0.95. During the validity study the translation validity of the scale was 0.89 and concurrent validity was 0.93 .

2.2.3. Self-Directed Learning Readiness Scale (SDLRS): The SDLRC developed by Fisher, King and Tague [47], was adapted into Turkish by Şahin and Erden [27]. When the structure of original scale of three items; self-management, motivation to learn and self-control skills, and results obtained from the Turkish version are compared, it was found that these three items were overlapped. Cronbach's alpha coefficients were 0.87 for the subscale of self-management, 0.86 for the subscale of motivation to learn and 0.79 for subscale of self-control skills. There are 40-item and 52-item scales of self-directed learning readiness scale. 52-item scale was used in this study.

\subsection{Research Design and Procedure}

The study which investigates the relationship between level of metacognitive awareness, level of self-directed learning readiness and academic achievement of preschool teacher candidates is a quantitative research and was designed in the survey model.

Before the research started, permissions were taken to use the scales, and then the study group of volunteered students from the preschool education department filled the each form in one week interval. Afterwards each student's forms were matched with each other.

\subsection{Data Analysis}

An appropriate statistical packet program was used for analysis of the data obtained during the research.

Regression analysis was done in order to test the relationship between the level of metacognitive awareness and level of self-directed learning readiness and academic achievement of the preschool teacher candidates. During the analysis of the data the level of significance was accepted as 0.05 . While the regression analysis was applied the assumptions below were taken into account and considered to be achieved during and before the analysis:

- A linear relationship between dependent and independent variables was identified.

- It was observed that there was not a multiple correlation between independent variables (Pearson correlation coefficient between the independent variables was found smaller than 0.70 )

- It was found that the error terms were distributed normally (normality).

- It was found that the variance of error terms was constant.

- It was identified that there was not a relationship between error terms and was found that the assumptions of multiple regression were occurred [46].

\section{Results}

The results of the statistical transactions with survey data is presented in this section. First, the level of relationship between the total score of the metacognitive awareness inventory and academic achievement, then the level of relationship between the self-directed learning readiness scale total score and academic achievement were analyzed by regression analysis. Later, the relationship between the level of metacognitive awareness and self-directed learning readiness was analyzed. Besides, the relationship between metacognitive awareness level of preschool teachers and self-management, motivation to learn and self-control subscales of self-directed learning readiness scale were analyzed by regression analysis. The following tables include the data of these analyses. 
Table 1. Relationship between metacognitive awareness level and academic achievement

\begin{tabular}{cccc}
\hline \multicolumn{3}{c}{ Dependent Variable: Academic achievement } \\
$\begin{array}{c}\text { Independent } \\
\text { Variable }\end{array}$ & Beta & $\mathrm{t}$ value & $\mathrm{p}$ value \\
Constant & 10.470 & 0.842 & 0.401 \\
Metacognition & -1.643 & -0.483 & 0.630 \\
$\mathrm{R}=0.41$ & $\mathrm{R}^{2}=0.002$ & $\mathrm{~F}$ value $=0.234$ & $\mathrm{p}=0.630$ \\
\hline
\end{tabular}

As shown in Table 1, a significant relationship between metacognitive awareness and academic achievement was not found $\left(\mathrm{R}=0.41 ; \mathrm{R}^{2}=0.002, \mathrm{~F}=0.234 ; \mathrm{p}=0.630\right)$. Looking at ANOVA values it was seen that the regression model was not statistically meaningful [46].

Table 2. Relationship between level of self-directed learning readiness and academic achievement

\begin{tabular}{cccc}
\hline \multicolumn{4}{c}{ Dependent Variable: Academic Achievement } \\
$\begin{array}{c}\text { Independent } \\
\text { Variable }\end{array}$ & Beta & $\mathrm{t}$ value & $\mathrm{p}$ value \\
constant & 10.844 & 1.467 & 0.145 \\
$\begin{array}{c}\text { Self-directed } \\
\text { Learning }\end{array}$ & -3.162 & -0.878 & 0.381 \\
$\mathrm{R}=0.074$ & $\mathrm{R}^{2}=0.005$ & $\mathrm{~F}=0.772$ & $\mathrm{p}$ value $=0.381$ \\
\hline
\end{tabular}

As shown in Table 2, not a significant relationship between level of self-directed learning readiness and academic achievement was found $\left(\mathrm{R}=0.074 ; \mathrm{R}^{2}=0.005\right.$, $\mathrm{F}=0.772 ; \mathrm{p}=0.381)$. Looking at ANOVA values it was seen that the regression model was not statistically meaningful [46].

Table 3. Relationship between level of metacognitive awareness and self-directed learning readiness

\begin{tabular}{cccc}
\hline \multicolumn{3}{c}{ Dependent Variable: Self-directed learning readiness } \\
$\begin{array}{c}\text { Independent } \\
\text { Variable }\end{array}$ & Beta & $\mathrm{t}$ value & $\mathrm{p}$ value \\
constant & 3.799 & 16.033 & 0.000 \\
Metacognition & -0.498 & -7.693 & 0.000 \\
$\mathrm{R}=0.532$ & $\mathrm{R}^{2}=0.283$ & $\mathrm{~F}=59.189$ & $\mathrm{p}$ value $=0.000$ \\
\hline
\end{tabular}

There was a moderate relationship between level of metacognitive awareness and self-directed learning readiness $\left(\mathrm{R}=0.532 ; \mathrm{R}^{2}=0.283 \mathrm{~F}=59.189 ; \mathrm{p}=0.000\right)$. So it can be said that the level of self-directed learning readiness tends to increase when the metacognitive awareness level of the individual increases.

At the tables below relationship between the subscales of the self-directed learning readiness level and metacognitive awareness level are examined independently.

Table 4. Relationship between "self-management" subscale and metacognitive awareness level

\begin{tabular}{cccc}
\hline \multicolumn{3}{c}{ Dependent Variable: Self-management } & \\
$\begin{array}{c}\text { Independent } \\
\text { Variable }\end{array}$ & Beta & $\mathrm{t}$ value & $\mathrm{p}$ value \\
constant & 5.805 & 17.343 & 0.000 \\
Metacognition & -0.416 & -4.550 & 0.000 \\
$\mathrm{R}=0.348$ & $\mathrm{R}^{2}=0.121$ & $\mathrm{~F}=20.699$ & $\begin{array}{l}\text { p value } \\
=0.000\end{array}$ \\
\hline
\end{tabular}

There was a low relationship between self-management subscale of self-directed learning readiness and level of metacognitive awareness $\left(\mathrm{R}=0.348 ; \mathrm{R}^{2}=0.121, \mathrm{~F}=20.699\right.$; $\mathrm{p}=0.000)$.

Table 5. Relationship between "motivation to learn" subscale and metacognitive awareness level

\begin{tabular}{cccc}
\hline \multicolumn{3}{c}{ Dependent Variable: Motivation to learn } \\
$\begin{array}{c}\text { Independent } \\
\text { Variable }\end{array}$ & Beta & $\mathrm{t}$ value & $\mathrm{p}$ value \\
constant & 3.922 & 15.613 & 0.000 \\
Metacognition & -0.506 & -7.373 & 0.000 \\
$\mathrm{R}=0.516$ & $\mathrm{R}^{2}=0.266$ & $\mathrm{~F}=54.359$ & $\mathrm{p}$ value $=0.000$ \\
\hline
\end{tabular}

There was a moderate relationship between motivation to learn subscale of self-directed learning readiness and level of metacognitive awareness $\left(\mathrm{R}=0.516 ; \mathrm{R}^{2}=0.266, \mathrm{~F}=54.359\right.$; $\mathrm{p}=0.000)$.

Table 6. Relationship between "self-control" subscale and metacognitive awareness level

\begin{tabular}{cccc} 
& \multicolumn{2}{c}{ Dependent Variable: Self-control } & \\
$\begin{array}{c}\text { Independent } \\
\text { Variable }\end{array}$ & Beta & t value & $\mathrm{p}$ value \\
constant & 4.153 & 13.617 & 0.000 \\
Metacognition & -0.572 & -6.865 & 0.000 \\
$\mathrm{R}=0.489$ & $\mathrm{R}^{2}=0.239$ & $\mathrm{~F}=47.133$ & $\mathrm{p}$ value $=0.000$ \\
\hline
\end{tabular}

There was a moderate relationship between self-control subscale of self-directed learning readiness and level of metacognitive awareness $\left(\mathrm{R}=0.489 ; \mathrm{R}^{2}=0.239, \mathrm{~F}=47.133\right.$; $\mathrm{p}=0.000)$.

\section{Conclusion}

The results of analyzing the relationship between the levels of metacognitive awareness, self-directed learning readiness and academic achievements of preschool teacher candidates are presented in this section.

Results of the research show that there is not a relationship between the levels of metacognitive awareness, self-directed learning readiness and academic achievement of the teacher candidates. Similarly, Schunk [20] in his article published in 2008, stated that the concepts of metacognition, self-regulation and readiness for self-regulation are not related to academic performance measurements. However, a relationship was detected between metacognitive awareness level and academic achievement in other identified researches [49-51]. Besides, Schraw and Sperling-Dennison [43] stated that individuals with high level of metacognitive awareness will get high academic achievements due to their success in planning, information management, monitoring, debugging strategies and evaluating. The findings of this research does not show a significant relationship between academic achievement and self-directed learning readiness as defined with the metacognitive skills either. However, some of the researches done in this area in Turkey stated 
reverse results to this research's findings. Karataş and Başbay [52] in their study conducted with university students, found positive meaningful relationship between critical thinking tendencies, academic achievement, general self-efficacy and self-directed learning readiness. This research shows that self-directed learning readiness level predicts critical thinking tendency, academic achievement and general self-efficacy. Similarly, Turan and Demirel [22] found out that students with high academic achievement play more active roles in their learning. Zimmerman [53] drew attention to the importance of self-regulation in academic motivation in his study and emphasized the correlation between academic achievement and self-regulation and self-directed learning indirectly. This case can be interpreted as teacher candidates studying preschool education have an education which allows them no need to use their metacognitive skills to get academic achievement during the third year of their education. At the same time it can be said that students studying in this department do not have a system that ensures leading their own learning.

It was detected that there was a moderate relationship between metacognitive awareness and self-directed learning readiness level. Looking at the findings of the research it can be said that when the metacognitive awareness level of the students increases self-directed learning readiness level of them tends to increase. As Baltaci and Akpınar's [40] statement of metacognition is related to individual's learning processes can be accepted as a similar finding with the meaningful relationship between metacognitive awareness and self-directed learning readiness level. Bembenutty [54] put forward that there is a relationship between feeling the knowing and self-regulation. This definition highlights the relation between metacognition and self-regulation. Besides in his research, Wolters [55] found out that looking through self-regulative learning perspective, students who are able to regulate their own learning can regulate their cognitive processes and metacognitive awareness and complete their tasks better when compared to others. Also Zimmerman [56] stated that students with self-regulative skills show appropriate behaviors towards selected goals and their own metacognitive processes. Mccombs and Marzona [57] pointed out that students with high self-regulative skills have opinion about their own knowledge in other words they had a high level of metacognitive awareness. It can be said that all these theories support the relationship between metacognitive/ self-regulative skills and self-directed learning readiness.

There was found a low relationship between metacognitive awareness level and self-directed learning readiness subscale "self-management", a moderate relationship between metacognitive awareness and "motivation to learn" and "self-control" subscales. Brockett and Hiemstra [24] emphasizes that self-directed learners should have self-management skills. This view is supported with the significant relationship between "self-management" subscale of self-directed learning readiness and metacognition. Results show that the effect of "motivation to learn" and "self-management" are more powerful on self-directed learning. "Motivation to learn" increases the motivation and level of attention of the learner and also increases the effort in learning process and learning outcomes [Pintrich, 2005 cited in 22]. Also, Zimmerman [58] pointed out that recent meta analytic studies showed that self regulated learning interventions include motivational strategies could improve learners' academic outcomes. Similarly, Collins [59] pointed out that learning motivation will increase as a result of self-directed learning readiness. The learner's control over his/her own learning increases with metacognitive awareness. Shunk and Ertmer [2005; cited in 22] stated that self-directed learning cannot occur in the absence of choosing and controlling. It can be said that students with high metacognitive awareness have more self-control during self-directed learning process when compared to others.

For individuals to become independent learners they should also have high self-directed learning skills and training independent learners is one of the most important goals of high education [22]. According to Boden [60] higher education institutions is the most appropriate environment to provide and improve self-directed learning readiness. In terms of higher education graduates to have these skills and also considering the effects of graduates who will serve as teachers, on students' metacognitive [17] and self-directed learning abilities [27], these skills should be gained by teacher candidates in education faculties. According to Kasworm [1997 cited in 52], when more learning opportunities are provided, more responsibilities are given to learners and when they are encouraged more to think, their self-management will increase. It can be thought that teachers with these skills can support them in students with their classroom management approaches and guidance given to students during learning processes. Karataş and Başbay [52] stated that, because self-directed learning is a wide concept and learning approach, it can be embedded into courses or can be taught separately and learning environment should be arranged according to this goal.

Not finding a statistically significant relationship between metacognitive awareness and self-directed learning readiness level and academic achievement, which was evaluated by the general point averages of preschool teacher candidates, can be interpreted as there isn't an evaluating and grading system in which these concepts effect the success evaluation of the students. Evaluating students' academic achievements in affection with these skills will make students put effort to gain these skills and will set the requirement to graduate gaining them. For this reason it can be claimed that academic evaluations should be arranged in a way that they are affected by these skills.

In this context, metacognitive awareness and self-directed learning readiness of students from departments outside preschool education department can be examined and compared with other departments. Other than this, researches to examine the effects of metacognitive awareness and self-directed learning readiness levels of serving teachers on 
the students' development, metacognitive skills and self-directed learning readiness level can be planned. Besides, education which supports metacognition and self-directed learning of the teachers and candidates can be planned or arrangements that support these skills can be made in their education programs, so planning of studies which researches the effects of these trainings and arrangements on teachers and teacher candidates can be suggested to researches.

\section{REFERENCES}

[1] S.G. Paris, A.H. Paris. Classroom applications of research on self-regulated learning, Educational Psychologist, Vol. 36, No. 2, 89-101, 2001. doi: 10.1207/S15326985EP3602_4

[2] N. Yürük. Özdüzenlemede üstbiliș [Metacognition in self-regulation], In G.Sakız (edt.) Özdüzenleme, Öğrenmeden öğretime özdüzenleme davranışlarının gelişimi, stratejiler ve öneriler [Self-regulation, development of self-regulative behaviors from learning to teaching, strategies and suggestions] (pp. 29-47), Nobel Press, Ankara, 2014.

[3] D.L. Dinsmore, P.A. Alexander, S.M. Loughlin. Focusing the conceptual lens on metacognition, self-regulation and self-regulated learning, Educational Psychology Review, 20, 391-409, 2008.

[4] J.H. Flavel. Metacognition and cognitive monitoring; A new area of cognitive-developmental inquiry. American Psychologist, 34(10), 906-911, 1979.

[5] M. Boekaerts. Self-regulated learning: where we are today, International Journal of Educational Research, Vol.31, 445$457,1999$.

[6] B. Bağçeci, B. Döş, R. Sarıca. İlköğretim öğrencilerinin üstbilişsel farkındalık düzeyleri ile akademik başarısı arasındaki ilişkinin incelenmesi $[\mathrm{An}$ analysis of metacognitive awareness levels and academic achievement of primary school students], Mustafa Kemal Üniversitesi Sosyal Bilimler Enstitüsü Dergisi / Mustafa Kemal University Journal of Social Sciences Institute, Vol.8, No.16, 551-556, 2011.

[7] D.A. Dunning, K. Johnson, J. Ehrlinger, J. Kruger, Why people fail to recognize their own incompetence. Current Directions in Psychological Science, Vol.12, No.3, 83-87, 2003.

[8] A. Desoete, H. Roeyers. Off-line metacognition a domain-specific retardation in young children with learning disabilities. Learning Disability Quarterly, Vol.25, 123-139, 2002.

[9] L .P Case, K. R. Harris, S. Graham. Improving the mathematical problem solving of students with learning disabilities: Self-regulated strategy development. The Journal of Special Education, Vol.26, 1-19, 1992.

[10] J. M. Alexander, K. E Johnson, J. Albano, T. Freygang, B. Scott. Relations between intelligence and the development of metaconceptual knowledge. Metacognition \& Learning, Vol.1, 51-57, 2006.
[11] M. V. J. Veenman, J. J. Beishuizen. Intellectual and metacognitive skills of novices while studying texts under conditions of text difficulty and time constraint. Learning and Instruction, Vol.14, 621-640, 2004.

[12] S. A. Coutinho. The Relationship between the need for cognition, metacognition, and intellectual task performance. Educational Research and Reviews, Vol.1, No.15, 162-164, 2006.

[13] S. Karakelle. Üst bilişsel farkındalık, zekâ, problem çözme algısı ve düşünme ihtiyacı arasındaki bağlantılar [Interrelations between metacognitive awareness, perceived problem solving, intelligence and need for cognition], Eğitim ve Bilim/Education and Science, Vol.37, No.164, 237-250, 2012.

[14] E.P. Haller, D.A. Child, H.J. Walberg. Can comprehension be taught? A quantitative synthesis of metacognitive studies. Educational Researcher, Vol.17, No.9, 5-8, 1988.

[15] B. Kramarski, Z.R. Mevarech. Enhancing mathematical reasoning in the classroom: The effects of cooperative learning and metacognitive training, American Educational Research Journal, Vol.40, No.1, 281-310, 2003.

[16] M.V.J. Veenman, J.J. Elshout, V.V. Busoto. Metacognitive mediation in learning with computer based simulations. Computers in Human Behavior, Vol.10, 93-106, 1994.

[17] M.V.J. Veenman, B.H.A.M. Van Hout-Wolters, P. Afflerbach, Metacognition and learning: Conteptual and methodological considerations. Metacognition and Learning, Vol.1, No.1, 3-15, 2006.

[18] P. Metallidou. Pre-service and in-service teachers' metacognitive knowledge about problem solving strategies. Teacher and Teacher Education, Vol.25, 76-82, 2009.

[19] M. Knowles. Self-directed learning: A guide for learners and teachers. New York: Associated Press. 1975.

[20] D.H. Schunk. Metacognition, self-regulation, and self-regulated learning: Research recommendations. Educational Psychology Review. Vol.20 No.4, 463-467. 2008, doi: 10.1007/s10648-008-9086-3.

[21] R. Hiemstra. Self-directed learning. In T. Husen \& T. N. Postlethwaite (Eds.), The International Encyclopedia of Education (2. edition), Oxford: Pergamon Press, 1994.

[22] S. Turan, Ö. Demirel. Öz-düzenleyici öğrenme becerilerinin akademik başarı ile ilişkisi: Hacettepe Üniversitesi Tıp Fakültesi örneği [The Relationship Between Self Regulated Learning Skills and Achievement: A Case from Hacettepe University Medical School]. Hacettepe Üniversitesi Eğitim Fakültesi Dergisi/Hacettepe University Journal of Education, Vol.38, 279-291, 2010.

[23] B. Lenz. Self-managed learning strategy systems for children and youth. Psychology Review. Vol.2, No.21. 211-229, 1992. ISSN: 0279-6015.

[24] R. Brockett, R. Hiemstra. Self-direction in adult learning, Perspectives on theory, research and practice, Routledge, London. 1991.

[25] M. S. Knowles. The Adult Learner: a neglected species (4th edition) Houston: Gulf Publishing, 1990.

[26] C. Patterson, D. Crooks, O. Lunyk-Child. A new perspective on competencies for self-directed learning. Journal Nurse 
Education, Vol.41, No.1, 25-31, 2002.

[27] E. Şahin, M. Erden. Özyönetimli Öğrenmeye Hazırbulunuşluk Ölçeği'nin geçerlik ve güvenirlik çalışması [Reliability and validity of Self-directed Learning Readiness Scale (SDLRS)], e-Journal of New World Sciences Academy, Vol.4, No.3, 695-706, 2009.

[28] E. A. Andersson, T. Z. Keith, A longitudinal test of a model of academic success for at-risk high school students. Journal of Educational Research, Vol.90, No.5, 259-268, 1997.

[29] V.V. Busato, F.J. Prins, J.J. Elshout, C. Hamaker. Intellectual ability, learning style, personality, achievement motivation and academic success of psychology students in higher education. Personality and Individual Differences, 6: 1057-1068, 1999.

[30] M. Boekaerts. Personality and the psychology of learning. European Journal of Personality, Vol.10, 377-404, 1996.

[31] T. Chamorro - Premuzic, A. Furnham, Self-assessed intelligence and academic performance. Educational Psychology, Vol. 26, No. 6, 769-779, 2006.

[32] I. Deary, S. Strand, P. Smith, C. Fernandes. Intelligence and educational achievement. Intelligence, Vol.35, 13-21, 2006.

[33] T. Farsides, R. Woodfield. Individual differences and undergraduate academic success: The roles of personality, intelligence, and application. Personality and Individual Differences, Vol.34, 1225-1243, 2003.

[34] G. Blickle. Personality traits, learning strategies, and performance. European Journal of Personality, Vol.10, 337352, 1996.

[35] B. De Raad, H.C. Schouwenburg. Personality in learning and education: A review. European Journal of Personality, Vol.10, 303-336, 1996.

[36] Ü. Sığrı, S. Gürbüz. Akademik başarı ve kişilik ilişkisi; Üniversite öğrencileri üzerinde bir araştırma [The relationship between personality and academic success: A study on undergraduates], Kara Harp Okulu Savunma Bilimleri Dergisi/The Journal of Defense Science, Vol.10, No.1, 30-48, 2011.

[37] R. N. Wolfe, S. D. Johnson. Personality as a predictor of college performance. Educational and Psychological Measurement, Vol.55, 177-185, 1995.

[38] E. Karagiannopoulou, P. Christtodoulides. The impact of Greek University students' perceptions of their learning environment on approaches to studying and academic outcomes. International Journal of Educational Research, Vol.43, 329-350, 2005.

[39] N.R. Kuncel, M. Crede, L.L. Thomas. The validity of self-reported grade point averages, class ranks, and test scores: A meta-analysis and review of the literature. Review of Educational Research, Vol. 75, 63-82, 2005.

[40] M. Baltacı, B. Akpınar. Web tabanlı öğretimin öğrenenlerin üstbiliş farkındalık düzeyine etkisi (The effect of web based instruction on the metacognition awareness levels of learners), Mustafa Kemal Üniversitesi Sosyal Bilimler Enstitüsü Dergisi/Mustafa Kemal University Journal of Social Sciences Institute, Vol.8, No.16, 319-333, 2011.

[41] A. Vrugt, F. Oort. Metacognition, achievement goals, study strategies and academic achievement: pathways to achievement. Metacognition Learning, Vol.30, 123-146, 2008.

[42] B.J. Zimmerman, Theories of self-regulated learning and academic achievement: An overview and analysis, In B.J. Zimmerman, \& D.H. Schunk, (Edi.)Self-regulated learning and academic achievement, Theoretical perspectives (pp.1-37). Routledge, 2001.

[43] G. Schraw, R. Sperling-Dennison. Assessing metacognitive awareness. Contemporary Educational Psychology, Vol.19, 460-470, 1994.

[44] B.J. Zimmerman, D.H. Schunk, Reflections on theories of self-regulated learning and academic achievement, In B.J. Zimmerman, \& D.H. Schunk, (Edi.)Self-regulated learning and academic achievement, Theoretical perspectives (pp.289-307). Routledge, 2001.

[45] G. Özsoy. Üstbiliş [Metacognition]. Türk Eğitim Bilimleri Dergisi/Turkish Journal of Educational Sciences, Vol.6, No.4, 713-740, 2008.

[46] A. Akın, R. Abacı, B. Çetin. Bilişötesi Farkındalık Envanteri'nin Türkçe formunun geçerlik ve güvenirlik çalışması [The validity and reliability study of the Turkish version of the Metacognitive Awareness Inventory]. Kuram ve Uygulamada Eğitim Bilimleri/Educational Science: Theory \& Practice, Vol.7, No.2, 655-680, 2007.

[47] M. Fisher, J. King, G. Tague. Development of a self-directed learning readiness scale for nurse education, Nurse Education Today, Vol.21, No.7, 516-525, 2001.

[48] B. Sipahi, S. Yurtkoru, M. Çinko. Sosyal bilimlerde SPSS'le veri analizi [Data analysis using SPSS in social sciences]. Beta Yayınları [Beta Printed Publishing], İstanbul, 2006.

[49] A. Desoete. Multi-method assessment of metacognitive skills in elementary school children: How you test is what you get. Metacognition Learning, Vol.3, No.3, 189-206, 2008.

[50] B. Kramarski. Promoting teachers' algebraic reasoning and self-regulation with metacognitive guidance, Metacognition Learning, Vol.3, No.2, 83-99, 2008.

[51] A. Young, J.D. Fry. Metacognitive awareness and academic achievement in college students, Journal of the Scholarship of Teaching and Learning, Vol.8, No.2, 1-10, 2008.

[52] K. Karataş, M. Başbay. Öz yönetimli öğrenmeye hazırbulunuşluk düzeyinin eleştirel düşünme eğilimi, genel öz yeterlik ve akademik başarı açısından yordanması [Predicting self directed learning readiness level in terms of critical thinking disposition, general self efficacy and academic achievement], İlkögretim Online /Elementary Education Online, Vol.13, No.3, 916-933, 2014.

[53] B. Zimmerman. Academic Studying and the Development of Personal Skill: A Self-Regulatory Perspective. Educational Psychologist. Vol.5, No.2/3, 73-86, 1998.

[54] H. Bembenutty. Feeling-of-knowing judgment and self-regulation of learning. Education, Vol.129, No. 4, 589-598, 2009.

[55] C. Wolters. The relation between high school students' motivational regulation and their use of learning strategies, effort, and classroom performance. Learning \& Individual Differences. 11(3). 281-301, 1999. ISSN: 1041-6080. 
[56] B. Zimmerman. Investigating self-regulation and motivation: Historical background, methodological developments, and future prospects. American Educational Research Journal, Vol. 45, No.1, 166-183, 2008.

[57] B. L. McCombs, R. J. Marzano. Putting the self in self-regulated learning: The self as agent in integrating skill and will. Educational Psychologist, Vol.25, 51-70, 1990.

[58] B.J. Zimmerman, Motivational sources and outcomes of self-regulated learning and performance, In B.J. Zimmerman
\& D.H. Schunk (eds.) Handbook of self-regulation of learning and performance (pp.49-64). Routledge, 2011.

[59] N. Collins. Motivation and Self-Regulated Learning: Theory, Research, and Applications. Journal of Higher Education, Vol.80, No.4. 476-479, 2009 ISSN: 0022-1546.

[60] C.J. Boden. Fostering learner self-direction in higher education: The key to preparing students for lifelong learning in a rapidly changing world. The multidimensional perspective. Learning and Instruction, Vol.13, 327-347, 2005. 